\title{
Benign Conjunctival Neoplasm
}

National Cancer Institute

\section{Source}

National Cancer Institute. Benign Conjunctival Neoplasm. NCI Thesaurus. Code C3622.

Abnormal growth of the cells of the conjunctiva without malignant characteristics. 